\title{
The Influence of Price \& Product Quality on Purchase Intention of Samsung A10S Mobile Phone
}

\author{
Fadhlan Ridhwana Sujana ${ }^{1, *}$ Agus Rahayu ${ }^{2,}$ Lili Adi Wibowo ${ }^{3,}$ Heny Hendrayati ${ }^{4}$ \\ ${ }^{1}$ Universitas Pendidikan Indonesia \\ ${ }^{2}$ Universitas Pendidikan Indonesia \\ ${ }^{3}$ Universitas Pendiidikan Indonesia \\ ${ }^{4}$ Universitas Pendidikan Indonesia \\ "Corresponding author.Email: ririn@upi.edu
}

\begin{abstract}
In this generation, online shopping is no longer considered taboo. This is supported by various applications that are familiar to people around the world. The pressure and influence of the people around can be one of the main reasons for it. Subjective norms and intention to use are the two variables used in this study. Data collection is done by distributing questionnaires via google form; This study aims to see whether subjective norms influence the intention to use Bandung city residents. The research method used in this research uses the descriptive analysis method, which describes the results obtained from questionnaires that have previously been distributed. This research aims to determine the number of people who are interested in using online applications. Respondents in the study were as many as 409 people consisting of study and lecturers in Bandung. The results obtained from this study are that subjective norms do no significantly affect the people of Bandung.
\end{abstract}

Keywords: intention to use, online shopping, subjective norm..

\section{INTRODUCTION}

There has been significant growth in the online environment. Online retailers must understand the reasons why online is now the choice. This is very important because online-oriented has very stiff competition from one store to another. This is homework on how online stores maintain or even increase so that old or new consumers come to their store and buy their products. This is based on a study that estimates that online retail will reach US \$ 269 billion in 2005, from US $\$ 45$ billion in 2000 [1], this illustrates that the new habits seen online have aroused people's interest. In considerable spending on academic researchers have begun to research the environmental impact of online shopping on consumers [2].

Currently, research in the real of information systems leads to illustrated things in the last few years. Information systems have changed the patterns of buying behavior by consumers. The large market potential is related to the current system. Cellular use has recently been increasing with changes in consumer behavior that have followed behind it. The increase in online shopping has existed in research conducted [3].

Subjective norms are wrong attitudes that depend on an individual's definition of the desires of influential people in his life. Subjective norms can be influenced by beliefs.

When shopping online, people are often influenced by people around when they buy for something, especially when shopping online where people who are new or have not recently used the shopping application people will ask how to shop online to avoid things that are not desirable, for example, in this case, is money that has been paid. However, the item has not been received, or in another example, it can be in the form of goods received that are not following what has been described in the relevant online shopping store. 
By shopping using online shopping, there will be more and more people who accept the convenience that is in it, more and more people are interested in shopping using online shopping, where there is a significant influence that people around users or new online shopping users will introduce more online shopping more broadly, especially in the capital city of Jakarta, where traffic conditions are very congested.

Shopping online, the customers will be easier when shopping. They will save time when shopping (no need to queue at the cashier) where in addition to the influence of people around who are accustomed to shopping online, shopping online will also make life easier for time to be more effective and efficient.

This research aims to determine the subjective norms of the intention to use Bandung, where Bandung residents are usually famous for their habits in the environment.

\subsection{Subjective Norm}

Previous research [4] found that young age is significant regarding subjective norm attitudes and website use. It is found that young people are variable that has a moderate influence on the intention to use online shopping. This finding is beneficial for online businesses in attracting and retaining young people, where young customers generate a response that they are delighted in shopping time.

Subjective norms. The typical can describe as social pressure that can be felt when doing or not doing a behavior [5]. This can illustrate that with social anxiety, social pressure will affect people when it is done in three different ways [6], where a norm can be measured from the point of view of other people's normative expectations as well as the person's motivation when they want their expectations. Can materialize. When doing a normative belief, it is recommended that this be seen as a determinant of subjective norms. The next stage will be built by the community's views [5], opinion, and expectations of certain groups from the community [7].

One of the things that can be extended from TAM is the use of the Theory of Reasoned Action. It shows that the subject's behavioral intention is done by combining two types of factors that combine a trait associated with behavior based on social influence. These are called subjective norms. In TRA, behavior depends on intention, and intention also depends on subjective norms.

\subsection{Intention to use}

The intention when behaving results of an assessment that comes from the future. When the intention to use it appears in a person, it must be positive and negative sides. The intention to use contains a preference from the individual to do [8].

Intention to use or intention to use is part of the basic TAM model, which can also be reflected in the studies considered, all of which have their research models. [9] in this case, is rather prominent because they have divided the intention to be used and the intention to buy, and the intention to find the thing to be used.

Based on TAM, the intention to use is always directly affected by the perceived benefits [10]. The perceived benefit is that the perceived use is defined as the level of individual confidence that using a particular system or technology will improve the quality of work [10].

H1: The effects of subjective norm on the intention to use in Jakarta City.

\section{METHODS}

\subsection{Population and Sample}

According to reference [11], Population is an abstract idea of a large set of cases that researchers take samples, and the results of these samples are generalized. The author determined the population for this study, namely Bandung resident consisting of 409 people, where the respondents consisted of students in the city of Bandung students were used as samples because students were literate in technology, especially in cellular technology, which has recently been popular anywhere and can be used anytime, the student who is taken is random as long as they understand online shopping so they can fill out the questionnaire in this study. [11] outlines that sample is a portion of the respondents from the population selected by the researcher from a large set and will generalize to the population. The sample used in this study is using a probability sampling method, namely simple random sampling.

The type of research in this research is quantitative. The number of samples in this study was 409 people consisting of the resident of the city of Bandung. The sampling technique in this study is that the sample is part of a population that has the same character as the population, where the sampling technique in this study uses a probability sampling technique, which is a sampling technique that provides equal opportunities for any unwanted population as a member of the sample. The analysis technique used in this research is the descriptive analysis technique by describing and interpreting each evaluated component's data. The data collected is then analyzed using a descriptive technique, which can be defined as the meaning of the data from each element to be assessed. When the data is diagnosed that has been collected, steps will be taken: scoring the 
respondents' answers, adding the total score of each component.

\section{RESULTS AND DISCUSSION}

In this variable, two variables are used, namely the subjective norm and the desire for this variable two variables are used; namely, the subjective norm and intention to use, in this study, want to know whether subjective criteria influence the desire to use or not. In this study, using, in this study, want to know whether subjective norms influence the desire to use. Table 1 . Show standardized regression weight.

Table 1. Standardized Regression Weights

\begin{tabular}{|c|c|c|c|c|}
\hline & Estimate & S.E. & C.R. & $\mathbf{P}$ \\
\hline $\begin{array}{l}\text { Intention to Use } \leftarrow \\
\text { Subjective Norm }\end{array}$ & 1,060 & ,134 & 7,928 & 7,928 \\
\hline $\begin{array}{l}\text { SN1 } \quad \leftarrow \\
\text { Subjective Norm }\end{array}$ & 1,000 & & & \\
\hline $\begin{array}{l}\text { SN2 } \quad \leftarrow \\
\text { Subjective }\end{array}$ & 1,656 & ,189 & 8,743 & 8,743 \\
\hline $\begin{array}{lc}\text { SN3 } & \leftarrow \\
\text { Subjective } & \text { Norm }\end{array}$ & ,866 & ,113 & 7,677 & 7,677 \\
\hline $\begin{array}{l}\text { SN4 } \quad \leftarrow \\
\text { Subjective }\end{array}$ & 1,059 & ,139 & 7,632 & 7,632 \\
\hline $\begin{array}{l}\text { ITU4 } \quad \leftarrow \\
\text { Intention to Use }\end{array}$ & 1,000 & & & \\
\hline $\begin{array}{l}\text { ITU3 } \leftarrow \\
\text { Intention to Use }\end{array}$ & ,970 & ,063 & $\begin{array}{l}15,30 \\
8\end{array}$ & 15,308 \\
\hline $\begin{array}{l}\text { ITU2 } \leftarrow \\
\text { Intention to Use }\end{array}$ & 1,1017 & ,065 & $\begin{array}{l}15,72 \\
3\end{array}$ & 15,723 \\
\hline $\begin{array}{l}\text { ITU1 } \leftarrow \\
\text { Intention to Use }\end{array}$ & 1,147 & ,072 & $\begin{array}{l}15,85 \\
1\end{array}$ & 15,851 \\
\hline
\end{tabular}

\section{- $\quad$ CFA test result}

From Table. 2 above, the output regression weight, when the value of $\mathrm{P}$ (probability) looks significant (above 0.05), the indicator must be deleted. It can be seen in the table above that all $\mathrm{P}$ values are above 0.05 ; all variables are at the probability that all of them meet the existing criteria.

In Table. 2, the goodness of fit was done here to all kinds of criteria, with the result given:Abbreviations and Acronyms.

Table 2. The goodness of Fit Test.

\begin{tabular}{|l|l|l|l|}
\hline $\begin{array}{c}\text { Goodness } \\
\text { of Fit }\end{array}$ & $\begin{array}{c}\text { Cut off } \\
\text { value }\end{array}$ & Result & Decision \\
\hline CMIN & $\leq 2,00$ & 3,237 & Bad Fit \\
\hline GFI & $\geq 0,90$ & 0,964 & Fit \\
\hline AGFI & $\geq 0,90$ & 0,931 & Fit \\
\hline CFI & $\geq 0,90$ & 0,967 & Fit \\
\hline TLI & $\geq 0,90$ & 0,951 & Fit \\
\hline NFI & $\geq 0,90$ & 0,953 & Fit \\
\hline IFI & $\geq 0,90$ & 0,967 & Fit \\
\hline RMSEA & $\leq 0,08$ & 0,074 & Fit \\
\hline RMR & $\leq 0,05$ & 0,038 & Fit \\
\hline
\end{tabular}

From the output Table. 2 above, it can be seen that the indicator value has met the excellent requirements where the conditions are fit with five indicators. This proves that the total model can be said to be fit, so there is no need to modify it.

From the results of data processing with the SEM AMOS program help, the path coefficients for each variable subjective norm on the intention to use can be found. It can be seen in the table above that the table can be seen; the coefficient of the path value is the Subjective Norm path coefficient on Intention to Use, which is based on table 4.1 the path coefficient for the subjective norm variable on Intention to Use is 1,060 , this shows that the influence of Subjective Norms on Intention to Use is equal to 1,060 , so the following equation intention to use $=1,060$ subjectiive norm is obtained Effect Subjective norm on the Intention to use using the bootstrap method shows a path coefficient value 1,060 ; this means that it is greater than 0,05 , so the variable subjective norm has no positive and significant effect on the intention to use the variable.

\section{CONCLUSION}

The conclusion of this study is based on the results obtained, and it can be concluded that variable subjective norms do not affect the intention to use. This illustrates that the Bandung people in this study decide to shop online is not significantly influenced by subjective factor norm, but more on other factors

\section{REFERENCES}

[1] E.B. Dykema, "On-line retail's ripple effect." September. Forrester Research Inc., Cambridge, MA, 2000.

[2] V. Swaminathan, E. Lepkowska-White, and B.P. Rao, "Browsers or buyers in cyberspace? An investigation of factors influencing electronic exchange," J. Computer-Mediated Communication., 1999.

[3] Number of apps available in leading app stores as of 4th quarter 2020. statista. 2020. [Online]. Avaible: https://www.statista.com/statistics/276623/numberof-apps-available-in-leading-app-stores/

[4] N.A. Hasbullah, A. Osman, S. Abdullah, S.N. Salahuddin, N.F. Ramlee, and H. M. Soha, "The relationship of attitude, subjective norm and website usability on consumer intention to purchase online: an evidence of Malaysian youth," Procedia Econ. Financ., 2016.

[5] I. Ajzen, "The theory of planned behavior," Organ. Behav. Hum. Decis. Process., 1991.

[6] M.M. Husin and A.A. Rahman, "What drives consumers to participate into family takaful schemes? A literature review," J. Islamic Marketing. 2013. 
[7] G. Xie, J. Zhu, Q. Lu, and S. Xu, "Influencing factors of consumer intention towards web group buying," in IEEE International Conf. on Industrial Engineering and Engineering Management, 2011.

[8] R.D. Blackwell, R.D. Miniard, and P.W. Engel, Consumer behavior. New York: HarcourtCollege Publishers, 2001.

[9] O. Gibreel, D.A. AlOtaibi, and J. Altmann, "Social commerce development in emerging markets," Electron. Commer. Res. Appl., 2018.
[10]F.D. Davis, A Technology acceptance model for empirically testing new-end user information systems: Theory and Result. Unpublished Ph.D. Dissertation, Sloan: Sloan School of Management, Massachusetss Institur of Technology (MIT), 1986.

[11]W. Neuman, Social Research Methods: Qualitative and Quantitative Approaches, Seventh Ed. Assex: Pearson Education Limited, 2014 